\title{
Electrical Equipment Waste City Home Improvement Issues from the Perspective of Governance Theory and Countermeasure Study
}

\author{
Li Songda \\ Department of Electric Power Engineering \\ North China Electric Power University \\ BaoDing China \\ 1209685656@qq.com
}

\author{
JIan Tiegu \\ Department of politics \\ North China Electric Power University \\ BaoDing China \\ jxqq12@qq.com
}

\begin{abstract}
Governance or public or private individuals and institutions management is the sum of many of the same services. It is made to reconcile conflicting or diverse interests of joint action and continuous process. It includes the right to force people to obey official institutions and rules and regulations, as well as various informal arrangements. And all the people and institutions or consent, or that match their interests and powers. Governance theory to solve the problem of urban domestic outfit waste electrical equipment provides a new way of thinking With the development of real estate industry, soaring urban housing, and electrical equipment waste city home improvement issues have been serious. Based on the outlet switch for example, woodcarvings, in the perspective of governance theory to study the electrical equipment waste city home improvement questions, and propose a solution.
\end{abstract}

Keywords-Governance theory; outlet switches ;waste; solutions

\section{RESEARCH BACKGROUND AND PROBLEMS}

In recent years, in the context of rapid economic development, China's housing construction is steadily developing, becoming an important growth targets.

With the improvement of people's living standards, as well as the rapid increase in residential areas, more and more people began to beautify their home and decoration. Especially in recent years, home decoration shows a rising trend. But the vast majority of buyers for housing electrical engineering requirements in the lack of awareness, so developers in housing construction have also been a corresponding reduction in electrical engineering share of attention. Home renovation waste has long been in existence, 2006 Chinese people used for House decoration costs 7500 billion Yuan to 8000 billion Yuan, wasted annually residential renovation of up to 3000 billion. Waste electrical equipment therein is the main aspect of the renovation process, but did not get the attention from all sides. Therefore, the study of electrical equipment waste problems in the home improvement process is of great significance. In theory, fills a gap in academic circles on study of home electrical equipment waste, widens the scope of research in the field of family decoration. In practice, benefit improvement of eco-consumption consciousness and promoting eco-consumption of habit; it helps to save the country's energy, promotes the development ofresource-saving society in China and to protection of the ecological environment, promoting the construction of ecological civilization in China.

\section{THE URBAN RESIDENTIAL WASTE ELECTRICAL EQUIPMENT PROBLEMS CAUSE ANALYSIS}

"Decorating a house in town, farmers can cover three-room". It vividly satiric home improvement in today's society there is huge waste problem. According to a survey, renovation process waste manifests primarily in switch, doors, light fixtures, fittings and so on. As we all know, residential power outlet switches have a close relationship with people's lives. This paper focuses on home improvement electrical waste problem. On the basis of a lot of reading, I think there are three main causes of wastage:

(A) The developer connection, a real estate development company engineering department staff to expose developers to make money, give owner is equipped with some old-fashioned or low quality products Developers only with profit as the only standard, equipped with low quality products for the owners, lead to the owners needed a second replacement of electrical equipment in domestic outfit, to bring economic burden to the owner not only, also creates a lot of waste of resources Developers simply to promote their own interests as the only standard, equipped with low quality products for building owners, leading owners needed a second replacement of electrical installations in the home not only to the economic burden on the owners, has also led to massive waste of resources.

(B) Decorate a design company, domestic outfit stylist more learn art, architecture, few of photoelectric lighting professional designers. Many designers in order to achieve visual effects design and complexity of the lights, causing electricity wasted. Some designers to improve the cost, tends to encourage consumers in the design of decoration increased, also result in additional functionality that is not practical or surface installations. "The ' guerrilla ' enterprise market disruption. Most consumers think, guerrilla ' decoration craft fair, and affordable, way more flexible. "(Jian Sun, 2006)" with the escalating competition in the market of furniture decoration market industry, all sorts of decorative materials store, urban and 
rural construction teams are still emerging, even there are a variety of rules does not speak of their companies in the industry "(Li Yuanlin, 2007)

(C) residents themselves, on the one hand, many residents after de-clutter their homes and moved into the new House, found the power socket switch design positions, such as unreasonable or too small, make it extremely inconvenient for users, resulting in tenants retrofitting and modification, or socket power strip has brought about colossal waste of electrical sockets and switches, and even a security risk. Therefore, appropriately designed outlet and switch configurations, can greatly reduce the related home improvement of waste electrical equipment has become an important basis for evaluation of residential electrical engineering standards. In addition, the original device was changed into the habit of most people when decorating, after some people to buy homes, being overly critical or too much the pursuit of personalized, original slightly dissatisfied with electrical equipment, then do the second renovation, resulting in significant waste.(xiaoxiang, 2006) therefore, decoration ideas home decoration by changing the electrical equipment is of great significance to solve waste problems. Eco-homes is one of the home improvement trend in the future, "eco-homes tend to be more on the function of the original state and the State of nature" (Sun Bingming, 2006) ecological residences in solve home electrical waste problem has a natural advantage.

(D) The deep: Above three points causes is caused city home electrical equipment of directly causes, current domestic of expert scholars on this also has himself of views: NA (2000) think "related family decoration material, and construction process, aspects of problem, management market of people understand is how thing, made decoration of decorative company also understand, but consumers not understand, When a dispute, it is difficult to reach a consensus, Consumers Association constantly receives complaints about home improvement. "that reflects the consumer's lack of home decoration materials, construction techniques and other aspects of knowledge. In addition, according to the acceptance of housing regulations, test power supply needed light fixtures, switches and Sockets, if it is not installed, then a home inspection does not pass. These led developers to benefit as a landlord are equipped with obsolete or low quality products. Therefore, acceptance also indirectly affects the provisions of home renovations for housing electrical equipment waste. In addition, less involved in home renovation waste laws and regulations in China and on electrical equipment waste in home decoration is almost blank, the lack of restrictions on developers use inferior products, and the control of consumer waste décor. Not only that, the real estate industry is missing on restrictions developers using shoddy home improvement and electrical equipment, decoration industries also lack the high cost designers design constraints. Within the home improvement industry in China's regulatory restrictions and regulations, there are some flaws.

Family to decorate the waste electrical equipment in China, including three aspects, one is when bridal chamber is decorated room electrical switches, sockets, lamps and lanterns of change caused by the waste; Second, consumers buy fine decoration room, because decorate the problem of designing waste and secondary decoration demolition and renovation cause waste; 3 it is secondhand the room decorate or consumer secondary when decorating, some can be repeated use of materials and can make use of waste caused by the waste of materials. (Mr. Peter Tsang Cheung, and2005) for renovation costs caused by, the Ministry of construction had been advocating for years decorated room, as this can reduce the waste of many decoration. However, the one-step decoration House in China lack of residential housing development in China $10 \%$, hardcover houses generally in developed countries accounted for amount of $80 \%$ or more. It reflected hardcover low levels of residential development in China. Therefore, in the national real estate boom, people purchased houses under the trend; countries should formulate relevant policies for housing developments and actively encourage people to buy hardcover, conducive to reducing the waste of home decoration.

\section{DRAWING LESSONS FROM EXTERNAL EXPERIENCE}

Above knows, my country outlet switch there is enormous waste problems, here's a look at the foreign studies on this issue and its countermeasures

New Zealand to prevent the socket switches waste a smart socket switch, can not only improve the life of the outlet switch, can also play a role in energy-saving. This method is worth people learning from. Such as the United States, most of the people used in switching power supply, switching power supply are a high-frequency, high reliability, low power consumption, low noise, interference, and modules. This increases the reliability of the switch, and power savings. As a result, improve the reliability of the switch, and save the electricity. Often the most important thing is this kind of switch without change, save the cost of replacement switch.

Because the outlet switch such appliances containing lead, mercury, cadmium, chromium, PVC and brominated flame retardants and other harmful substances, throw great harm to the environment and human health. Such as $\mathrm{cFc}$ 12 and blowing agents cFc-11, andHCFC_22 were destroying the ozone layer, caused by the greenhouse effect, if not treated properly, it will cause serious pollution of air, soil and water, and harm human health, and can even affect to the next generation. Meanwhile, waste outlet switch, there are many resources available, such as non-ferrous metals, ferrous metals, plastics, glass, Tin, carbon can be recycled.

In recent years, some developed countries have enacted and implemented the WEEE-related laws and regulations, and Japan of the home appliance recycling law, promulgated in 2001 years 4 months of formal implementation. Its televisions, refrigerators, air conditioners and washing machines of four appliances recycling, manufacturers, distributors, and consumers should assume their respective obligations, consumers should be junked appliances sent to the Recycle Bin, and pay a recycling fee. Appliance manufacturers and importers to recycling and commercial obligations, recovery from waste household appliances must be in proportion to a useful resource, to make products for sale, recovery, separation and recycling of waste home appliances plastic build circulating economic system of today's three-axis is the one of the factors. EU has 
expanded from $80 \%$ of the landfill method of waste plastics turned vaporized recycling methods. Germany chemical recycling is the world's oldest countries, plastics recycling more than 40\%; East Germany SVZ from 20 century 50 eras, using waste plastics to produce methanol and electricity, $1000 \mathrm{~kg}$ waste plastics to produce $769 \mathrm{~kg}$ methanol. Generation 1 28mWEU. Australia reproductions for home appliances like Japan also began to pay attention to the material recycling method recycling part regeneration costs borne by consumers and partly through advertising and the sale of recycled materials added. As Australia's codmc company dealing with household electronics $80 \%$ come from the Association of home appliance, $20 \%$ by value of sales of recycled materials. United States plastics Association (SPI) on plastic surfaces are required to stamp a clear identification, which greatly simplifies recovery, facilitating material recycling. Japan is the world's home appliance recycling and recycling management system most technologically advanced countries, consumers were established throughout the country, streets, waste recycling, recycling business is the very appliance recycling network and recycling business networks, a clear division of labor.

Outlet switch design, full consideration in foreign countries is conducive to improving the efficiency of plastics recycling materials design and product design, are consistent with home appliances Association's "high possibility of recycling", "disassembly, sorting easier", crushing, separation, easy " 3R assessment system design. These measures are worthy of our reference.

\section{ELECTRICAL EQUIPMENT WASTE CITY HOME IMPROVEMENT SOLUTIONS}

According to the above analysis we can see that traditional government-centered model has been unable to effectively promote urban home improvement of waste electrical equipment to solve the problem, we need effective governance theory to solve home electrical equipment waste services. Therefore, to solve home electrical waste problem, required not only the Government, but also need to mobilize social forces, would have to be formed, "led by Government, market operation, the active community participation" model of governance. This governance mode has potential advantage, these advantage performance in :"can reflect place residents diversification of needs preference, and resources configuration of efficiency sex, and effective of incentive mechanism, and reasonable decentralization, and public service provides and production of competitive supply, and public service system produced of marginal cost reduced and proceeds maximize, and maintained place public service provides of flexibility and responded sex, and encourages community and citizens autonomy management, and beneficiaries right enjoys of fair sex," It can be said that urban home electrical equipment waste treatment corresponds to a comprehensive system. Only fully mobilize the initiative and enthusiasm, and effectively manage, in an integrated and sustainable development as the goal of efficient use of resources to promote urban home electrical equipment waste problem to solve.
From theory of governance, we solve the problem of home electrical equipment waste puts a few pieces of advice:

\section{A. Governmental ecological responsibility}

\section{awareness-raising, strengthening service functions}

Governance city home electrical equipment waste problem not only is environmental of requirements, is achieved "full, and coordination, and sustainable development" of due of meaning, face challenge, Government not only to in system, and technology, and funds, and propaganda, multifaceted efforts, also has training government itself of ecological responsibility consciousness, advocate low carbon consumption concept, formed subject spirit, to really real are of up to subject guide of role, to from essentially reverse current environment, and ecological, and energy of dilemma. The harmonious interaction of man and society, and promote the overall sustainable development of the economy.

(1) States to strengthen Interior management of electrical equipment for business and engineering, home decoration, formulate and improve relevant laws and regulations. And publicity, determined implementation of national laws and regulations and technical standards related to resource conservation, to fill gaps in home electrical equipment waste in the process, make laws to go by, the standard Developer's opportunistic behavior. Countries and strongly promote energy-saving home improvement and electrical equipment and technology, encourage people to use energy-efficient electrical equipment and reasonable purchase of interior lighting systems, using energy-efficient lighting and appliances to reduce the consumption of energy in China. China's energy-saving home improvement electrical equipment that has not been promoted in home improvement, countries formulate related policies to encourage home electrical equipment and the use of technology in home improvements in building a resource-conserving and environment-friendly society in China is of great significance.

(2) Country hardcover housing development. Countries formulate related policies, encouraging the development of real estate industry hardcover to encourage consumers to buy the hardcover, hardcover housing measures for the development of Western developed countries for reference to promote and improve the hardcover volume of residential development in China. Hardbound room of development for our country electrical equipment is of important significance to solve waste problems.

\section{B. Facing the market: market mechanism into full play}

(1) The decoration industry in the development of industry standards, and strengthening industry supervision. Decoration industry should be adjusted according to actual development housing approval standards, bring it into line with the development of a resource-saving society. Uniform industry standards within the industry and regulating the behavior of people in the industry. Improved supervision within the industry, help to reduce the occurrence of home electrical equipment waste. Decoration industry should also improve construction 
savings. To decorate the House, determined to prevent any major changes in split, savage improper construction or material selection and construction of security, environmental protection and quality accident brought by redoing the.

(2) Strengthening vocational training within the industry, improve the quality of employees. Home staff should establish conservation awareness, strengthen job training, helps establish ethics-oriented, so as to reduce unnecessary waste problems in the home improvement happen. Designers in charge of home decoration, should pay attention to design. Design is one of the largest conservation savings.

\section{Community self-governance: the broad participation}

\section{of citizens and other social organizations}

(1) The consumer should establish eco-consumption consciousness and establish the safety, environmental protection, energy efficiency and saving in the whole society of interior decoration concept and ecological consumer behavior. Currently forcing developers for decoration is not the case, if the water saving, energy saving and thermal insulation materials used in the decoration, you can save $50 \%$ energy. If preference-all links are used instead of expensive decoration materials will save $20 \%$ the renovation costs. When consumers buy home electrical equipment should be actively buying energy-efficient products. Consumers should also increase knowledge on home improvement, proper material selection, and proper selection. Consumer shall be strictly prohibited the use of State announced the phase-out of products with high energy consumption, high pollution and low efficiency. In material aspects, in accordance with the requirements of circular economy, attention to the comprehensive utilization of resources, maintenance and conservation of renewable resources.

(2) To enhance household communication designers, and contractors. Zhai Yan, Zhao Yuguo (2004): "a successful home renovation, to rely on joint efforts of Heads of household and professional designers. Heads should have a higher rate of literacy, to rationally recognize the connotation of decoration ; For designers , in addition to having a high design and construction experience, but also communicate actively with the heads, know family member preferences, patterns of life, as well as residential structures, piping layouts, the surrounding environment, And agree with your own design ideas with heads, an understanding between each other, coupled with good construction, home renovation in order to achieve the desired results. "Indeed, good communication can make home appliance devices fully meet household demand, play to their maximum effect. According to surveys by decoration companies design the living room, dining room, bedroom, kitchen and other inter-departmental model number, customers pick out favorite each plate, and by Designer are combined, and the overall style is unified. Thus, preliminary budget and design time by $2 / 3$ or more. Decoration company reduces the cost, owners of the spend is reduced accordingly; the traditional manual methods, not only slow progress, material loss as high as $8 \%$. And plant decoration mechanized production, assembly line operations, not only shorten the duration 15 days or more, also reached no fraction of material loss rate control in $2 \%$, make the renovation costs $10 \%$ per cent. household economy to communicate with builders and designers to communicate, to reduce unnecessary waste in home improvement, so as to protect their own interests.

Along with the economic and social development, people are increasingly buying houses and electrical equipment waste in the home decoration has become an acute problem. Needs joint efforts from all sides to solve waste problems. Home decorating process waste problem solved on the formation of a resource-saving and environment-friendly society in China is of great significance.

\section{CONCLUSION}

China is now in a period of rapid economic and social development, but at this stage our economy development environmental and resource pressures, and control home electrical equipment waste issue is not only the requirements of environmental protection, economic "comprehensive, coordinated and sustainable development" the basic path, is international cooperation, participation in international competition inevitable move.

For governance city home electrical equipment waste problem this has been yǐ lái was ignored of problem, can said is a challenge, Government needed from system, and technology, and funds, and propaganda, multifaceted started, vigorously established and perfect conducive to governance city home electrical equipment waste problem of system, active encourages enterprise for technology innovation, implemented to "low carbon, and environmental, and can continued" for core of green development mode, full played market of regulation role, established science of regulatory system, Strengthening governance electrical equipment waste city home improvement information and outreach, community training to control home electrical equipment waste, formation of consciousness conducive to control wasteful habits of home improvement you equipment and the establishment of green economic development model, in order to fundamentally reverse the current plight of the environment, ecology, energy, the harmonious interaction of man and society, and promote economic development. In short, we should use to control home electrical waste problem, and this as a breakthrough, building, green economy and low-carbon economy adapt to modes of production and consumption patterns, do model for other areas, and ultimately realize the coming of the new era of green, low-carbon economy of the whole China and even the whole earth to truly become economic and social, human and nature harmonious development of society.

\section{REFERENCES}

[1] Mr. Peter Tsang Cheung, Su. Home improvement annual waste exceeding 300 million [n]. China quality daily, 2005/09/08008.

[2] Xiaoxiang . Changsha home renovation waste each year about 5000 USD [n]. China building materials News, 2006/08/08001.

[3] Na. To be renovated first class decoration quality guaranteed--remember the basis is clearly preferred building material decoration market [j]. China economic information, 2000, 10:48-49.

[4] Zhai Yan, Zhao Yuguo. Status quo and thinking on modern home decoration [j]. Journal of environmental management College of China, 2004, 04:124-126. 
[5] Sun Baiying.When governance facing the challenges ahead [m]. Beijing: National Publishing House

[6] Jian Sun. long way home decoration "repairable" far [j]. the mass standardization. 2006 (06).
[7] Sun Bingming. ecological environment and home furnishings discussion on the reform of modern home decor [j]. Art education. $2006(01)$

[8] Li Yuanlin. Reflections on some problems of modern home interior design [j]. Art panorama. 2007 (05) 